\title{
REVIEW
}

\section{MANAGEMENT OF NON-HEALING WOUNDS WITH HONEY DRESSINGS: A LITERATURE REVIEW}

\author{
Dana Vyhlídalová ${ }^{1}$, Radka Kozáková ${ }^{2}$, Renáta Zeleníková \\ ${ }^{I}$ Department of Nursing and Midwifery, Faculty of Medicine, University of Ostrava, Czech Republic (student) \\ ${ }^{2}$ Department of Nursing and Midwifery, Faculty of Medicine, University of Ostrava, Czech Republic
}

Received January 30, 2018; Accepted May 11, 2018. Copyright: This is an open access article distributed under the terms of the Creative Commons Attribution International License (CC BY). http://creativecommons.org/licenses/by/4.0/

\begin{abstract}
Aim: The aim of the literature review was to identify the effectiveness of products containing honey in the management of nonhealing wounds. Design: A literature review. Methods: Based on predefined criteria, studies were searched in the electronic databases PubMed, Science Direct, EBSCO and Google Scholar between 2007 and 2017. Using the PRISMA recommendations, twenty studies were selected and analyzed. Results: Studies assessed in the review investigated the mean wound healing time, number (percentage) of completely or partly healed cases, pain intensity, odor and antibacterial activity of honey. Most frequently, the efficiency of honey was assessed in diabetic and lower leg ulcers, with wounds of varied etiology being investigated in the majority of studies. The outcomes of most studies showed a shorter mean healing time, higher percentages of completely healed wounds and more effective eradication of wound infection. Only three studies reported no significant improvement in the treatment of lower leg and diabetic ulcers and malignant wounds with honey. Conclusion: Honey is an effective substance in the management of wounds and may be used at any phase of healing for any types of wounds providing that the patient's allergies to some components of dressings are ruled out.
\end{abstract}

Keywords: diabetic ulcers, honey, lower leg ulcers, Manuka honey, non-healing wounds, odor, pain, pressure ulcers, secretion.

\section{Introduction}

Non-healing wounds are a global health problem affecting approximately $1-2 \%$ of the population. They often result from severe underlying conditions and diseases of affluence such as diabetes mellitus, chronic venous insufficiency, peripheral artery disease, immobility and cancer (Stryja et al., 2011). Successful therapy for non-healing wounds requires substantial knowledge and skills concerning not only the pathophysiology of various types of these wounds but also therapeutic materials used to treat wounds. At present, the pharmaceutical industry offers a wide range of such materials with varied effects and prices. Long-term treatment of wounds is both unpleasant for the patient and costly. The healing process is often complicated by the development of infection with bacterial resistance to antibiotic therapy. Honey dressings are beneficial for several reasons. Honey has been shown to have antimicrobial and antiinflammatory effects, boost the immune system's

\footnotetext{
Corresponding author: Dana Vyhlídalová, Charita Šternberk, Opavská 13, Šternberk, Czech Republic; email: dana.vyhlidalova@sternberk.charita.cz
}

activity, promote debridement and stimulate the wound regeneration process (Oryan, Alemzadeh, Moshiri, 2015). Additionally, it has antioxidant and immunomodulatory properties and it may be used at any stage of healing.

In wound care, honey is a suitable substance because of its biological activity and physical properties. Honey viscosity provides a protective barrier preventing infection from entering the wound; the high sugar content has an osmotic effect reducing bacterial multiplication and growth. The high osmotic pressure draws water from the wound. As a result, microorganisms become dehydrated and die. Lymph is moved from the subcutaneous tissue to the wound surface, aiding in the removal of necrotic and devitalized tissue, the so-called autolytic debridement. Thus, honey provides the conditions for wet healing, prevents the secondary dressing from sticking to the wound and decreases pain at dressing changes (Molan 2006; Oryan, Alemzadeh, Moshiri 2015).

In wound healing, the antimicrobial activity of honey is much appreciated. The high levels of antimicrobial substances in honey may effectively inhibit viable bacteria of resistant strains. This findings is currently 
very important as microbial resistance to antibiotic therapy has been increasing (Kwakman et al., 2008; Oryan, Alemzadeh, Moshiri, 2015).

One of the main components of antimicrobial activity is hydrogen peroxide. Its low concentration promotes healing through proliferation of fibroblasts and epithelial cells, stimulates angiogenesis and increases blood supply to ischemic areas (Alam et al., 2014). Another factor contributing to the antimicrobial activity of honey is its acid $\mathrm{pH}$ inhibiting many pathogenic bacteria. The $\mathrm{pH}$ value ranges from 2.3 to 4.5 .

The antioxidant activity of honey is provided by various compounds, the most important of which are phenolic substances and gallic acid, antioxidants scavenging free radicals. The compositions of honey allows it to affect the immune system. It stimulates B and $\mathrm{T}$ cells and activates neutrophilic phagocytosis. In inflammation, it enhances antibody production during primary and secondary immune responses to antigens (Oryan, Alemzadeh, Moshiri, 2015).

The antiinflammatory effects of honey lead to a reduction in the number of inflammatory cells, vasodilation and wound swelling. They increase blood, nutrient and oxygen supply to the wound and aid in pain relief (Alam et al., 2014). Honey also neutralizes the unpleasant odor accompanying nonhealing wounds by neutralizing nitric acid and sulfur dioxide (Biglari et al., 2013). The antimicrobial activity of manuka honey is expressed as the socalled Unique Manuka Factor (UMF). It is equivalent concentration of phenol with identical antimicrobial activity against Staphylococcus aureus (i.e. UMF 15 $=15 \%$ mixture of phenol). The UMF was artificially defined to determine the concentration, quality and antimicrobial potential of honey dressings (Mrázová, Stryja, Poch, 2014).

\section{Aim}

The aim of the literature review was to identify the effectiveness of products containing honey in the management of non-healing wounds.

\section{Methods}

\section{Design}

A literature review.

\section{Eligibility criteria}

To meet the objective, the following PICO question was formulated:

May honey dressings (I) used in the treatment of nonhealing wounds in patients over 18 years of age $(\mathrm{P})$ lead to faster healing and less secretion, odor and pain $(\mathrm{O})$ as compared to management with products containing povidone-iodine or nanocrystalline silver (C)?

$\mathrm{P}$ (population) - patients over 18 years of age with non-healing wounds

I (intervention) - wound management with honey dressings

C (comparison) - wound management with povidone-iodine or nanocrystalline silver

O (outcome) - less secretion, odor and pain; shorter wound healing time

To perform the analysis, research studies on the management of non-healing wounds of varied etiology with natural or modified honey in patients over 18 years of age and published in 2007-2017 were searched. The eligibility criteria were as follows: English or Czech language; full text of the article; a study of adult patients with non-healing wounds managed with honey dressings or honey products; types of studies: systematic reviews, randomized controlled trials, prospective interventional studies.

The exclusion criteria were: studies on the management of acute wounds with honey dressings; application of honey into body cavities; animal studies.

Included in the review were studies with the highest level of evidence, that is, meta-analyses, systematic reviews, randomized controlled trials (RCTs) and prospective studies. The levels of evidence of the studies were assessed using the Hierarchy of Evidence for Intervention Studies table (Jarošová, Zeleníková, 2014).

\section{Sources}

The data sources were articles found in the electronic databases PubMed, Science Direct, EBSCO and Google Scholar.

\section{Search}

Relevant articles were searched between July and September 2017 using the keywords: manuka honey, honey, non healing wounds, leg ulcers, diabetic foot ulcers, pressure ulcers, pain, odour, secretion and the Boolean operators OR and AND. Excluded were duplicate articles, studies not meeting the eligibility criteria or those irrelevant to the issue under investigation such as those on oral administration of honey in gastrointestinal diseases. Another exclusion criterion was a lower level of evidence.

\section{Study selection}

In the international electronic databases, a total of 848 relevant documents were found using the above search strategy and defined criteria. 
Subsequently, they were classified based on the eligibility and exclusion criteria.

\section{Data analyses}

In the retrieved studies, the title, abstract and topic of the article were evaluated. Further, duplicate and specific studies were excluded. Of all the retrieved relevant documents, twenty articles were consistent with the study's aim and were thus included in the review (Figure 1).
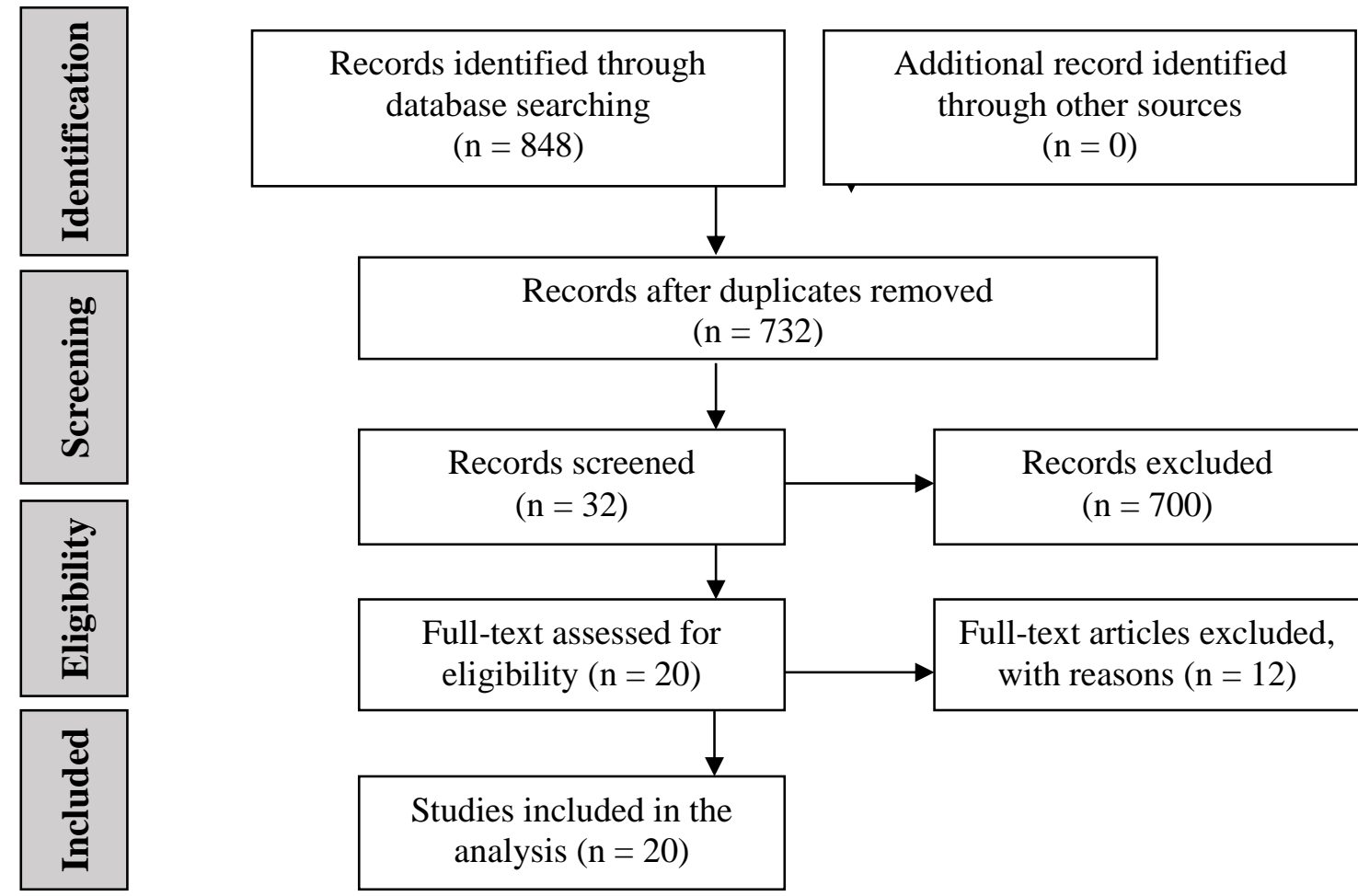

$$
(\mathrm{n}=0)
$$

Figure 1 Selection of studies (PRISMA flow chart)

\section{Results}

In the scientific literature, research studies concerned with the effect of honey on hon-healing wounds. Among 13 primary studies retrieved, eight were RCTs and five were prospective studies (Table 1). The prospective studies (Vandeputte, Van Waeyenberge, 2007; Moghazy et al., 2010; Biglari et al., 2013; Tellechea et al., 2013; Mohamed et al., 2015) reported the course of healing of leg ulcers of varied etiology. The studies by Vandeputte, Van Waeyenberge (2007) and Tellechea et al. (2013) tested a honey-containing product called L-Mesitran ${ }^{\circledR}$; in the other studies, natural honey was used. Vandeputte, Van Waeyenberge (2007) also reported results of honey antibacterial activity testing.

In the retrieved RCTs, honey of various origin, most frequently natural, sterilized honey, was used to manage wounds in intervention groups. Only Moghazy et al. (2010) and Shukrimi et al. (2008) used unpasteurized honey. In control groups, wounds were managed with povidone-iodine (Shukrimi et al., 2008; Gulati et al., 2014) and nanocrystalline silver (Lund-Nielsen et al., 2011; Tsang et al., 2017). In the other studies, dressings used in controls were not specified; yet the studies yielded interesting findings.

The numbers of participants in the assessed studied ranged from 10 to 375 . Mostly, those were adults; only the prospective study by Biglari et al. (2013) included patients under 18 years of age as well. Six studies investigated the effect of honey on the management of diabetic ulcers (Shukrimi et al., 2008; Moghazy et al., 2010; Kamaratos et al., 2012; Al Saeed, 2013; Imran, Hussain, Baig, 2015; Tsang et al., 2017). Lower leg ulcers were studied by Jull et al. (2008) and Tellechea et al. (2013). A Danish RCT by Lund-Nielsen et al. (2011) reported the healing process of malignant wounds. The remaining studies dealt with wounds of varied etiology. All authors reported the follow-up time, wound healing time and number (percentage) of healed cases. 
Table 1 An overview of primary studies

\begin{tabular}{|c|c|c|c|c|c|}
\hline $\begin{array}{l}\text { Author(s) } \\
\text { (year) }\end{array}$ & Country & $\begin{array}{l}\text { Type of } \\
\text { study }\end{array}$ & Age & Sample & Intervention \\
\hline $\begin{array}{l}\text { Vandeputte, Van } \\
\text { Waeyenberge (2007) }\end{array}$ & Belgium & prospective & mean, 72 years & $\begin{array}{l}\mathrm{n}=89 \\
\text { varied etiology }\end{array}$ & L-Mesitran ${ }^{\circledR}$ \\
\hline $\begin{array}{l}\text { Moghazy et al. } \\
(2010)\end{array}$ & Egypt & prospective & mean, 52.3 years & $\begin{array}{l}\mathrm{n}=30 \\
\text { diabetic ulcers }\end{array}$ & unpasteurized natural honey \\
\hline Biglari et al. (2013) & Germany & prospective & $\begin{array}{l}\text { mean, adults, } 56 \text { years } \\
\text { mean, under } 18 \text { 's, } 8.8 \\
\text { years }\end{array}$ & $\begin{array}{l}\mathrm{n}=121 \\
\text { varied etiology }\end{array}$ & $100 \%$ antibacterial honey \\
\hline $\begin{array}{l}\text { Tellechea et al. } \\
\text { (2013) }\end{array}$ & Portugal & prospective & $\begin{array}{l}\text { mean, } 73 \text { years } \\
\text { (range, } 57-83 \text { years) }\end{array}$ & $\begin{array}{l}\mathrm{n}=10 \\
\text { lower leg ulcers }\end{array}$ & L-Mesitran ${ }^{\circledR}$ \\
\hline $\begin{array}{l}\text { Mohamed et al. } \\
\text { (2015) }\end{array}$ & Qatar & prospective & range, $37-76$ years & $\begin{array}{l}\mathrm{n}=12 \\
\text { varied etiology }\end{array}$ & unpasteurized natural honey \\
\hline Jull et al. (2008) & $\begin{array}{l}\text { New } \\
\text { Zealand }\end{array}$ & $\mathrm{RCT}$ & over 18 years & $\begin{array}{l}\mathrm{n}=368 \\
\text { lower leg ulcers }\end{array}$ & $\begin{array}{l}\text { manuka honey } \\
(\mathrm{n}=187) \\
\text { usual care } \\
(\mathrm{n}=181)\end{array}$ \\
\hline Shukrimi et al. (2008) & Malaysia & $\mathrm{RCT}$ & $\begin{array}{l}\text { mean, } 52.1 \text { years } \\
\text { (range, } 47-63 \text { years) }\end{array}$ & $\begin{array}{l}\mathrm{n}=30 \\
\text { diabetic ulcers }\end{array}$ & $\begin{array}{l}\text { non-sterile pure honey } \\
(\mathrm{n}=\text { not stated) } \\
\text { povidone-iodine } \\
(\mathrm{n}=\text { not stated })\end{array}$ \\
\hline $\begin{array}{l}\text { Lund-Nielsen et al. } \\
\text { (2011) }\end{array}$ & Denmark & $\mathrm{RCT}$ & range, $47-90$ years & $\mathrm{n}=69$ & $\begin{array}{l}\text { manuka honey } \\
(\mathrm{n}=34) \\
\text { nanocrystalline silver } \\
(\mathrm{n}=35)\end{array}$ \\
\hline $\begin{array}{l}\text { Kamaratos et al. } \\
(2012)\end{array}$ & Greece & $\mathrm{RCT}$ & mean, 56 years & $\begin{array}{l}\mathrm{n}=63 \\
\text { neuropathic diabetic ulcers }\end{array}$ & $\begin{array}{l}\text { manuka honey } \\
(\mathrm{n}=32) \\
\text { conventional dressings } \\
(\mathrm{n}=31)\end{array}$ \\
\hline Al Saeed (2013) & $\begin{array}{l}\text { Saudi } \\
\text { Arabia }\end{array}$ & $\mathrm{RCT}$ & range, $52-58$ years & $\begin{array}{l}\mathrm{n}=59 \\
\text { diabetic ulcers }\end{array}$ & $\begin{array}{l}\text { manuka honey } \\
(\mathrm{n}=32) \\
\text { conventional dressings } \\
(\mathrm{n}=27)\end{array}$ \\
\hline Gulati et al. (2014) & India & $\mathrm{RCT}$ & mean, 42 years & $\begin{array}{l}\mathrm{n}=45 \\
\text { varied etiology }\end{array}$ & $\begin{array}{l}\text { sterilized honey } \\
(\mathrm{n}=23) \\
\text { povidone-iodine } \\
(\mathrm{n}=22)\end{array}$ \\
\hline $\begin{array}{l}\text { Imran, Hussain, Baig } \\
\text { (2015) }\end{array}$ & Pakistan & RCT & $\begin{array}{l}\text { mean, } 54 \text { years } \\
\text { (range, } 47-63 \text { years) }\end{array}$ & $\begin{array}{l}\mathrm{n}=375 \\
\text { diabetic ulcers }\end{array}$ & $\begin{array}{l}\text { natural, sterile honey } \\
(\mathrm{n}=195) \\
\text { saline } \\
(\mathrm{n}=180)\end{array}$ \\
\hline Tsang et al. (2017) & Hong Kong & $\mathrm{RCT}$ & mean, 65 years & $\begin{array}{l}\mathrm{n}=31 \\
\text { diabetic ulcers }\end{array}$ & $\begin{array}{l}\text { manuka honey } \\
(\mathrm{n}=10) \\
\text { nanocrystalline silver } \\
(\mathrm{n}=11) \\
\text { conventional dressings } \\
(\mathrm{n}=10)\end{array}$ \\
\hline
\end{tabular}

The effect of honey on pain levels perceived during treatment was investigated in a prospective study by Biglari et al. (2013). The result showed that the mean pain levels reported by patients decreased significantly from 1.71 at the beginning of the study to 0.55 at the end. Initially, analgesics during dressing changes were required by $17 \%$ of patients; at the final wound assessment, the rate dropped to as low as 4\%. In their RCT, Gulati et al. (2014) measured pain with a visual analog scale (VAS). The initial mean value as reported by patients was 7 ; after six weeks, this dropped to 1 and 5 in the intervention and control groups, respectively. Similar results were yielded by Mohamed et al. (2015). During therapy using honey, patients' pain decreased from a VAS value of 8 at the beginning of the study to 1 at the end. Additionally, the authors observed deodorant effects of honey. Half of patients reported that odor decreased substantially or even disappeared in the first week of treatment. In a RCT by Shukrimi et al. (2008), there was reduction of odor from ulcers after dressing and dressing procedure was less painful as the honey dressing did not adhere to the granulating surface. None of the studies dealt with wound secretions. The results of primary studies related to healing time are summarized in Table 2. 
Table 2 Results of primary studies

\begin{tabular}{|c|c|c|c|c|}
\hline $\begin{array}{l}\text { Author(s) } \\
\text { (year) }\end{array}$ & $\begin{array}{l}\text { Results } \\
\text { Follow-up time }\end{array}$ & Healing time & Healed/unhealed wounds & $\begin{array}{l}\text { Conclusions and authors' } \\
\text { recommendations }\end{array}$ \\
\hline $\begin{array}{l}\text { Vandeputte, Van } \\
\text { Waeyenberge } \\
\text { (2007) }\end{array}$ & not stated & $\begin{array}{l}\text { mean, } 32 \text { days } \\
\text { (range, } 3-180 \text { days) }\end{array}$ & $100 \%$ completely healed & $\begin{array}{l}\text { - honey accelerates the healing process } \\
\text { - it reduces the bacterial activity in the } \\
\text { wound }\end{array}$ \\
\hline $\begin{array}{l}\text { Moghazy et al. } \\
(2010)\end{array}$ & not stated & mean, 2.3 weeks & $\begin{array}{l}43.3 \% \text { completely healed } \\
43.3 \% \text { partly healed } \\
6.6 \% \text { amputations } \\
6.6 \% \text { skin grafts }\end{array}$ & $\begin{array}{l}\text { - honey is an effective dressing in the } \\
\text { treatment of diabetic ulcers } \\
\text { - it is cost-effective } \\
\text { - it prevents infection with resistant bacterial } \\
\text { strains }\end{array}$ \\
\hline $\begin{array}{l}\text { Biglari et al. } \\
(2013)\end{array}$ & not stated & mean, 4.8 weeks & $\begin{array}{l}31.4 \% \text { completely healed } \\
68.6 \% \text { partly healed }\end{array}$ & $\begin{array}{l}\text { - honey is effective in the treatment of } \\
\text { various types of wound in all age groups } \\
\text { - it reduces pain } \\
\text { - it promotes autolytic debridement }\end{array}$ \\
\hline $\begin{array}{l}\text { Tellechea et al. } \\
\text { (2013) }\end{array}$ & not stated & $\begin{array}{l}\text { mean, } 101 \text { days } \\
\text { (range, 28-176 } \\
\text { days) }\end{array}$ & $\begin{array}{l}70 \% \text { completely healed } \\
30 \% \text { partly healed }\end{array}$ & - honey is effective and easy to use \\
\hline $\begin{array}{l}\text { Mohamed et al. } \\
(2015)\end{array}$ & not stated & mean, 23.8 days & $100 \%$ completely healed & $\begin{array}{l}\text { - honey is effective in wound healing } \\
\text { - it reduced pain and odor }\end{array}$ \\
\hline Jull et al. (2008) & 12 weeks & not stated & $\begin{array}{l}\text { manuka honey: } \\
55.6 \% \text { completely healed } \\
44.4 \% \text { partly healed } \\
\text { usual care: } \\
49.7 \% \text { completely healed } \\
50.3 \% \text { partly healed }\end{array}$ & $\begin{array}{l}\text { - honey-impregnated dressings failed to } \\
\text { significantly improve healing of lower leg } \\
\text { ulcers, compared to usual care }\end{array}$ \\
\hline $\begin{array}{l}\text { Shukrimi et al. } \\
\text { (2008) }\end{array}$ & not stated & $\begin{array}{l}\text { honey: } \\
\text { mean, } 14.4 \text { days } \\
\text { (range, } 7-26 \text { days) } \\
\text { iodine: } \\
\text { mean, } 15.4 \text { days } \\
\text { (range, } 9-36 \text { days) }\end{array}$ & not stated & $\begin{array}{l}\text { - wounds heal equally fast with honey as } \\
\text { with povidone-iodine } \\
\text { - honey reduces edema and odor } \\
\text { - honey dressing changes were less painful }\end{array}$ \\
\hline $\begin{array}{l}\text { Lund-Nielsen et } \\
\text { al. (2011) }\end{array}$ & 4 weeks & not stated & $\begin{array}{l}\text { manuka honey: } \\
0 \% \text { healed } \\
\text { NAg: } \\
0 \% \text { healed }\end{array}$ & $\begin{array}{l}\text { - there was no statistically significant } \\
\text { difference between the two groups with } \\
\text { respect to wound size, secretion, odor and } \\
\text { pain } \\
\text { - both types of dressings are recommended } \\
\text { for malignant wounds }\end{array}$ \\
\hline $\begin{array}{l}\text { Kamaratos et al. } \\
(2012)\end{array}$ & not stated & $\begin{array}{l}\text { honey: } \\
\text { mean, } 31 \text { days } \\
\text { controls: } \\
\text { mean, } 43 \text { days }\end{array}$ & $\begin{array}{l}\text { manuka honey: } \\
\text { 97\% completely healed } \\
\text { CD: } \\
90 \% \text { completely healed }\end{array}$ & $\begin{array}{l}\text { - manuka honey has a positive effect on the } \\
\text { haling time in neuropathic ulcers, with no } \\
\text { need to use antibiotics }\end{array}$ \\
\hline Al Saeed (2013) & $\begin{array}{l}6 \text { weeks / } 6 \\
\text { months in both } \\
\text { groups }\end{array}$ & not stated & $\begin{array}{l}\text { honey: after } 6 \text { weeks } \\
61.3 \% \text { completely healed } \\
\text { honey: after } 6 \text { months } \\
87.1 \% \text { completely healed } \\
\text { CD: after } 6 \text { weeks } \\
11.5 \% \text { completely healed } \\
\text { CD: after } 6 \text { months } \\
42.3 \% \text { completely healed }\end{array}$ & $\begin{array}{l}\text { - honey application is more effective in } \\
\text { eradicating infection in the wound } \\
\text { - it promotes healing } \\
\text { - it reduces the number of minor amputations } \\
\text { in diabetic ulcers }\end{array}$ \\
\hline $\begin{array}{l}\text { Gulati et al. } \\
\text { (2014) }\end{array}$ & 6 weeks & not stated & $\begin{array}{l}\text { honey: } \\
31 \% \text { completely healed } \\
\text { povidone-iodine: } \\
0 \% \text { completely healed }\end{array}$ & $\begin{array}{l}\text { - honey is highly effective in the healing } \\
\text { process, compared to povidone-iodine } \\
\text { - it reduces pain and increases patient } \\
\text { comfort }\end{array}$ \\
\hline $\begin{array}{l}\text { Imran, Hussain, } \\
\text { Baig (2015) }\end{array}$ & not stated & $\begin{array}{l}\text { honey: } \\
18 \text { days } \\
\text { saline: } \\
29 \text { days }\end{array}$ & $\begin{array}{l}\text { honey: } 75.97 \% \text { completely } \\
\text { healed; } 17.87 \% \text { unhealed } \\
\text { saline: } 57.39 \% \text { completely } \\
\text { healed; } 31.36 \% \text { unhealed }\end{array}$ & $\begin{array}{l}\text { - honey-impregnated dressings significantly } \\
\text { shorten the healing time }\end{array}$ \\
\hline $\begin{array}{l}\text { Tsang et al. } \\
(2017)\end{array}$ & not stated & $\begin{array}{l}\text { NAg: } \\
\text { mean, } 11.45 \text { weeks } \\
\text { honey: } \\
\text { mean, } 12.8 \text { weeks } \\
\text { CD: } \\
\text { mean, } 14.7 \text { weeks }\end{array}$ & $\begin{array}{l}\text { NAg: } \\
81.8 \% \text { completely healed } \\
\text { honey: } \\
50 \% \text { completely healed } \\
\text { CD: } \\
40 \% \text { completely healed }\end{array}$ & $\begin{array}{l}\text { - nanocrystalline silver is potentially better } \\
\text { than manuka honey and conventional } \\
\text { dressings in diabetic ulcer healing, in terms } \\
\text { of healing time and wound size reduction }\end{array}$ \\
\hline
\end{tabular}


For overall assessment of secondary studies, one meta-analysis and six systematic reviews were selected (Table 3). The secondary studies were published between 2008 and 2017. The numbers of studies included in individual reviews ranged from four (Tian et al., 2014) to 55 (Vandamme et al., 2013). Based on defined criteria, the authors included RCTs, prospective studies and case studies in their systematic reviews. A meta-analysis was conducted by Medhi et al. (2008) to assess the effectiveness of topical application of honey in wound healing in both observational studies and RCTs.
The authors of the systematic reviews concluded that honey was effective in the management of nonhealing wounds of varied etiology; moreover, Vandamme et al. (2013) highlighted its antibacterial effect and elimination of MRSA. However, all the authors consistently claimed that for some factors evaluated in studies, the levels of evidence were rather low (e.g. odor or pain) and recommended more randomized studies to be conducted. Results and recommendations from the systematic reviews are summarized in Table 4.

Table 3 Summary of systematic reviews and meta-analyses

\begin{tabular}{|c|c|c|c|}
\hline $\begin{array}{l}\text { Author(s) } \\
\text { (year) }\end{array}$ & Country & $\begin{array}{l}\text { Number of included } \\
\text { studies (year of } \\
\text { publication) }\end{array}$ & Systematic review objective \\
\hline Medhi et al. (2008) & India & $15(1966-2008)$ & $\begin{array}{l}\text { To evaluate the efficacy of topical application of honey in RCTs and } \\
\text { observational studies on wound healing }\end{array}$ \\
\hline $\begin{array}{l}\text { Vandamme et al. } \\
\text { (2013) }\end{array}$ & Belgium & 55 (1988-2012) & $\begin{array}{l}\text { To evaluate the available evidence and the role of honey in contemporary } \\
\text { wound care }\end{array}$ \\
\hline $\begin{array}{l}\text { Asamoah, Ochieng, } \\
\text { Meetoo (2014) }\end{array}$ & Canada & $5(2004-2010)$ & $\begin{array}{l}\text { To assess whether honey as a topical wound dressing is beneficial in } \\
\text { promoting the healing of diabetic foot ulcers }\end{array}$ \\
\hline Tian et al. (2014) & China & $4(2008-2013)$ & $\begin{array}{l}\text { To objectively evaluate the effectiveness of honey dressings in the treatment } \\
\text { of diabetic foot ulcers }\end{array}$ \\
\hline $\begin{array}{l}\text { Holland, Norris } \\
\text { (2015) }\end{array}$ & $\begin{array}{l}\text { United } \\
\text { Kingdom }\end{array}$ & 5 (2004-2009) & $\begin{array}{l}\text { To determine whether the use of medical grade honey as compared to } \\
\text { standard wound therapy improves clinical outcome in the management of } \\
\text { chronic venous leg ulcers }\end{array}$ \\
\hline Jull et al. (2015) & $\begin{array}{l}\text { New } \\
\text { Zealand }\end{array}$ & $26(1991-2014)$ & $\begin{array}{l}\text { To assess the effects of honey compared with alternative wound dressings } \\
\text { and topical treatments on the healing of acute and/or chronic wounds }\end{array}$ \\
\hline $\begin{array}{l}\text { Watts, Frehner } \\
\text { (2016) }\end{array}$ & Australia & 30 (1999-2016) & $\begin{array}{l}\text { To obtain the best available evidence regarding the use of medical grade } \\
\text { honey for wound management }\end{array}$ \\
\hline
\end{tabular}

\section{Discussion}

This literature review aimed to identify the effectiveness of products containing honey in the management of non-healing wounds and to answer the clinical question whether honey dressings used in the treatment of these wounds in patients over 18 years of age may lead to faster healing and less secretion, odor and pain as compared to dressings containing povidone-iodine or nanocrystalline silver. The results of retrieved studies provide evidence for answering the clinical question.

Studies assessed in the review investigated the mean wound healing time and number (percentage) of completely or partly healed cases; some studies provide data on pain intensity perceived by patients and odor reduction as compared with controls; prospective studies also describe phases in the course of healing. Some studies reported on antibacterial activity of honey. Several studies have been reported on the antibacterial activity of honey, which contributes to the eradication of wound infection and the destruction of antibiotic-resistant bacterial strains (Vandeputte, Van Waeyenberge, 2007; Moghazy et al., 2010; Al Saeed, 2013)
Comparative studies used nanocrystalline silver or povidone-iodine in control groups. In some studies, dressings used in controls were not specified. Several studies on honey effectiveness explicitly stated that wounds were of the same etiology, for example neuropathic diabetic ulcers (Kamaratos et al., 2012), venous leg ulcers (Jull et al., 2008) or malignant wounds in cancer patients (Lund-Nielsen et al., 2011). In most studies, however, wounds were of mixed etiology.

The most investigated type of non-healing wounds in both primary studies and systematic reviews was diabetic foot ulcers. The findings, however, were inconsistent. Four studies (Moghazy et al., 2010; Kamaratos et al., 2012; Al Saeed, 2013; Imran, Hussain, Baig, 2015) demonstrated beneficial effects of honey on ulcer healing. The results showed a shorter mean healing time, higher percentages of completely healed wounds and more effective eradication of wound infection. Moghazy et al. (2010) found honey therapy to be cost-effective. Al Saeed (2013) reported the percentage of amputated toes in patients in the intervention group. Considerably fewer amputations were carried 
Table 4 Results and recommendations from systematic reviews

\begin{tabular}{|c|c|c|}
\hline $\begin{array}{l}\text { Author(s) } \\
\text { (year) }\end{array}$ & Results & $\begin{array}{l}\text { Recommendation for clinical practice and } \\
\text { further research }\end{array}$ \\
\hline $\begin{array}{l}\text { Medhi et al. } \\
(2008)\end{array}$ & $\begin{array}{l}\text { - high efficiency of honey in observational studies (99\% of cases } \\
\text { completely healed) } \\
\text { - RCTs show moderate efficiency of honey ( } 56 \% \text { of cases } \\
\text { completely healed) } \\
\text { - some RCTs failed to show higher efficiency of honey as compared } \\
\text { with controls }\end{array}$ & $\begin{array}{l}\text { - topical application of honey is beneficial in } \\
\text { wound healing but larger prospective } \\
\text { randomized studies are needed }\end{array}$ \\
\hline $\begin{array}{l}\text { Vandamme et } \\
\text { al. (2013) }\end{array}$ & $\begin{array}{l}\text { - honey had wound healing stimulating properties } \\
\text { - available evidence for deodorizing and wound pain reducing } \\
\text { properties is low }\end{array}$ & $\begin{array}{l}\text { - larger and well randomized studies need to be } \\
\text { performed }\end{array}$ \\
\hline $\begin{array}{l}\text { Asamoah, } \\
\text { Ochieng, } \\
\text { Meetoo (2014) }\end{array}$ & $\begin{array}{l}\text { - honey is effective in the treatment of diabetic ulcers } \\
\text { - however, there is a lack of quality evidence to support and guide } \\
\text { clinical practice }\end{array}$ & - more randomized studies need to be performed \\
\hline $\begin{array}{l}\text { Tian et al. } \\
(2014)\end{array}$ & $\begin{array}{l}\text { - honey may be more effective in decreasing overall treatment time } \\
\text { - it facilitates debridement } \\
\text { - it promotes angiogenesis and granulation tissue formation; it } \\
\text { accelerates wound healing }\end{array}$ & $\begin{array}{l}\text { - due to a small quantity of published studies, } \\
\text { large, multicenter studies are needed }\end{array}$ \\
\hline $\begin{array}{l}\text { Holland, Norris } \\
\text { (2015) }\end{array}$ & $\begin{array}{l}\text { - smaller RCTs show improved outcomes of honey therapy when } \\
\text { compared with standard approaches } \\
\text { - larger RCTs show no benefit of honey therapy }\end{array}$ & $\begin{array}{l}\text { - future RCTs must examine particular clinical } \\
\text { outcomes (time to healing, reduction in pain) } \\
\text { - the efficacy of honey in more acute settings } \\
\text { should be examined }\end{array}$ \\
\hline $\begin{array}{l}\text { Jull et al. } \\
(2015)\end{array}$ & $\begin{array}{l}\text { - honey dressings heal burns more quickly than conventional } \\
\text { dressings } \\
\text { - honey heals acute and chronic wounds more quickly than SSD } \\
\text { (low quality evidence) } \\
\text { - honey may heal infected post-operative wounds more rapidly than } \\
\text { povidone-iodine (low quality evidence) } \\
\text { - the effects of honey relative to controls are unclear for venous leg } \\
\text { ulcers, diabetic foot ulcers and minor acute wounds (low quality } \\
\text { evidence) }\end{array}$ & $\begin{array}{l}\text { - studies comparing treatment of wounds with } \\
\text { honey and silver should be performed } \\
\text { - studies evaluating treatment of infected } \\
\text { wounds with honey } \\
\text { - studies should focus on populations with } \\
\text { wounds of the same etiology }\end{array}$ \\
\hline $\begin{array}{l}\text { Watts, Frehner } \\
\text { (2016) }\end{array}$ & $\begin{array}{l}\text { - there is evidence supporting the use of medical-grade honey in the } \\
\text { treatment of non-healing wounds } \\
\text { - honey is effective in eliminating odor in the wound } \\
\text { - due to honey's osmotic effect, there may be increased levels of } \\
\text { exudate }\end{array}$ & $\begin{array}{l}\text { - before applying a honey dressing, ensure the } \\
\text { patient is not allergic to honey } \\
\text { - to avoid potential development of microbial } \\
\text { resistance, only use honey with high } \\
\text { antimicrobial activity (UMF } 15+\text { ) }\end{array}$ \\
\hline
\end{tabular}

SSD - silver sulfadiazine; UMF - Unique Manuka Factor

out in the group treated with honey. Similar conclusions were drawn by Moghazy et al. (2010). In a study by Shukrimi et al. (2008), wound odor and pain were reduced; the difference in healing time was not statistically significant. Tsang et al. (2017) found that nanocrystalline silver was more effective in the treatment of diabetic ulcers, in terms of both the mean healing time and the rate of completely healed wounds. Tian et al. (2014) claimed that honey may positively influence the overall treatment time; however, they recommended additional multicenter studies to be conducted to confirm the efficiency of honey.

The retrieved studies suggest a positive role of honey in the treatment of lower leg ulcers. In their prospective study, Tellechea et al. (2013) followed ulcers with a mean duration of 3.3 years before the study was initiated. During the study, either wounds healed completely or their size decreased significantly in all patients; the mean treatment time was 101 days. A significant reduction in the size of lower leg ulcers was also found by other authors (Vandeputte, Van Waeyenberge, 2007; Mohamed et al., 2015). The only exception was Jull et al. (2008) reporting no significant improvement in the healing of venous ulcers over 12 weeks as compared with usual care. Moreover, honey was found to promote healing of wounds of other etiologies.

Honey has antibacterial properties and is highly effective against a wide range of bacterial strains including Staphylococcus aureus, Pseudomonas aeruginosa, Streptococcus spp. and MRSA. It is beneficial in wound desloughing, reducing bacterial load and facilitating transition to the granulation phase. The use of honey in wound management decreases the consumption of antibiotics and topical antiseptics (Biglari et al., 2013). Given the fact that the antibacterial effects of honey are multifactorial, the development of bacterial resistance to this substance is unlikely (Eddy et al., 2008). An unpleasant aspect of sloughy wounds is their odor that may be, at least partly, eliminated by the use 
of honey. The deodorant effects were not mentioned in all studies; odor reduction was confirmed by Shukrimi et al. (2008) and Mohamed et al. (2015). Some studies investigated pain intensity in topical application of honey. In some cases, patients reported stinging sensations following application of honey to the wound, resolving spontaneously within two hours. This sort of pain was more perceived by patients with arterial ulcers. The unpleasant feelings in the wound are caused by changing $\mathrm{pH}$ in various types of honey (Mohamed et al., 2015).

This review results have demonstrated that honey may be an effective substance in the management of wounds and may be used at any phase of healing for any types of wounds. It is necessary to know the patient's allergy history; honey is not recommended in patients allergic to bee stings and honey products. The application of food honey to the wound may be associated with a risk for activation of bacterial spores and possible transmission of tetanus (Stryja, 2011).

\section{Conclusions}

Although honey has been used in wound management for centuries, now it is only slowly introduced into medical practice, often with distrust. This may be due to a lack of information on this treatment modality. The application of honey dressings have a positive impact on the healing process. In addition to its antibacterial properties, honey aids in removing necrotic debris and slough from the wound base. This is particularly beneficial in, for example, grade 3 and 4 pressure ulcers (according to the EPUAP classification), diabetic or lower leg ulcers. Honey promotes angiogenesis and granulation tissue formation, facilitating the transition to epithelization. Therefore, honey may be applied at any phase of healing. In the Czech Republic, no study on the effectiveness of honey in the healing process has been conducted and there is no systematic review of literature on this issue. The present review of studies concerned with the management of non-healing wounds has shown rather positive outcomes of the use of honey dressings.

\section{Ethical aspects and conflict of interest}

All the resources used are properly cited. The authors are not aware of any conflict of interest.

\section{Acknowledgments}

Supported by project no. SGSO8/LF/2017-2018 The efficacy of dressings containing honey in treatment of non-healing wounds.

\section{Author contributions}

Conception and design (DV, RZ), data collection (DV), data analysis and interpretation (DV), manuscript draft (DV), critical revision of the manuscript (RK, RZ), final approval of the manuscript (DV, RK, RZ).

\section{References}

Al Saeed M. Therapeutic efficacy of conventional treatment combined with manuka honey in the treatment of patients with diabetic foot ulcers: a randomized controlled study. The Egyptian Journal of Hospital Medicine. 2013;53:1064-1071. Alam F, Islam A, Gan SH, Khalil I. Honey: a potential therapeutic agent for managing diabetic wounds. EvidenceBased Complementary and Alternative Medicine. Volume 2014; Article ID 169130, 16 pages [cited 2017 Aug 21]. Available from: https://www.hindawi.com/journals/ecam/2014/169130/cta/ Asamoah B, Ochieng B, Meetoo D. The clinical role of honey in treating diabetic foot ulcers: a review. Diabetic Foot Canada. 2014;2(2):30-34.

Biglari B, Moghaddam A, Santos K, Blaser G, Büchler A, Jansen G, Längler A, Graf N, Weiler U, Licht V, Strölin A, Keck B, Lauf V, Bode U, Swing T, Hanano R, Schwarz NT, Simon A. Multicentre prospective observational study on professional wound care using honey (Medihoney ${ }^{\mathrm{TM}}$ ). International Wound Journal. 2013;10(3):252-259.

Eddy JJ, Gideonsen MD, Mack GP. Practical considerations of using topical honey for neuropathic diabetic foot ulcers: a review. WMJ: official publication of the State Medical Society of Wisconsin. 2008;107(4):187-190.

Gulati S, Qureshi A, Srivastava A, Kataria K, Kumar P, Ji AB. A prospective randomized study to compare the effectiveness of honey dressing vs. povidone iodine dressing in chronic wound healing. The Indian Journal of Surgery. 2014;76(3):193-198.

Holland LC, Norris JM. Medical grade honey in the management of chronic venous leg ulcers. International Journal of Surgery. 2015;20:17-20.

Imran M, Hussain MB, Baig M. A randomized, controlled clinical trial of honey-impregnated dressing for treating diabetic foot ulcer. Journal of the College of Physicians and Surgeons - Pakistan: JCPSP. 2015;25(10):721-725.

Jarošová D, Zeleníková R. Ošetřovatelství založené na důkazech. Evidence Based Nursing. 1. vyd. Praha: Grada Publishing, a.s.; 2014. (in Czech)

Jull AB, Cullum N, Dumville JC, Westby MJ, Deshpande S, Walker N. Honey as a topical treatment for wounds. Cochrane Database of Systematic Reviews. 2015;3:CD005083.

Jull A, Walker N, Parag V, Molan P, Rodgers A; Honey as Adjuvant Leg Ulcer Therapy trial collaborators. Randomized clinical trial of honey-impregnated dressings for venous leg ulcers. British Journal of Surgery. 2008;95(2):175-182. 
Kamaratos A, Tzirogiannis K, Iraklianou S, Panoutsopoulos G, Kanellos I, Melidonis A. Manuka honey-impregnated dressings in the treatment of neuropathic diabetic foot ulcers. International Wound Journal. 2014;11(3):259-263.

Kwakman PH, Van den Akker JP, Güçlü A, Aslami H, Binnekade JM, de Boer L, Boszhard L, Paulus F, Middelhoek $\mathrm{P}$, te Velde AA, Vandenbroucke-Grauls CM, Schultz MJ, Zaat SA. Medical-grade honey kills antibiotic-resistant bacteria in vitro and eradicates skin colonization. Clinical Infectious Diseases: an Official Publication of the Infectious Diseases Society of America. 2008;46(11):1677-1682.

Lund-Nielsen B, Adamsen L, Kolmos HJ, Rørth M, Tolver A, Gottrup F. The effect of honey-coated bandages compared with silver-coated bandages on treatment of malignant wounds - a randomized study. Wound Repair and Regeneration: official publication of the Wound Healing Society [and] the European Tissue Repair Society. 2011;19(6):664-670.

Medhi B, Puri A, Upadhyay S, Kaman L. Topical application of honey in the treatment of wound healing: a meta analysis. Alternative Medicine. 2008;10(4):166-169.

Moghazy AM, Shams ME, Adly OA, Abbas AH, El-Badawy MA, Elsakka DM, Hassan SA, Abdelmohsen WS, Ali OS, Mohamed BA. The clinical and cost effectiveness of bee honey dressing in the treatment of diabetic foot ulcers. Diabetes Research and Clinical Practice. 2010;89(3):276281.

Mohamed H, Salma MA, Al Lenjawi B, Abdi S, Gouda Z, Barakat N, Elmahdi H, Abraham S, Hamza AH, Al Khozaei D, Al Majid S, Al Majid H, Abdini J, Al Jaber M, Al Masseh F, Al Ali AA. The efficacy and safety of natural honey on the healing of foot ulcers: a case series. Wounds. 2015;27(4):103114.

Molan PC. Using honey in wound care. International Journal of Clinical Aromatherapy. 2006;3(2):21-24.

Mrázová R, Stryja J, Poch T. Medová krytí v moderním wound managementu. Hojení ran. 2014;8(1):31-32. (in Czech)
Oryan A, Alemzadeh E, Moshiri A. Biological properties and therapeutic activities of honey in wound healing: a narrative review and meta-analysis. Journal of Tissue Viability. 2016;25(2):98-118.

Shukrimi A, Sulaiman AR, Halim AY, Azril A. A comparative study between honey and povidone iodine as dressing solution for Wagner type II diabetic foot ulcers. The Medical Journal of Malaysia. 2008;63(1):44-46.

Stryja J, Krawczyk P, Hájek M, Jalůvka F. Repetitorium hojení ran 2. 1. vyd. Semily: Geum; 2011. (in Czech)

Tellechea O, Tellechea A, Teixeira V, Ribeiro F. Efficacy of honey gel in the treatment of chronic lower leg ulcers: a prospective study. EWMA Journal. 2013;13(2):35-39.

Tian X, Yi LJ, Ma L, Zhang L, Song GM, Wang Y. Effects of honey dressing for the treatment of DFUs: a systematic review. International Journal of Nursing Sciences. 2014;1(2):224-231.

Tsang KK, Kwong EW-Y, Shun To TS-S, Chung JW-Y, Wong TK-S. A pilot randomized, controlled study of nanocrystalline silver, Manuka honey, and conventional dressing in healing diabetic foot ulcer. Evidence-Based Complementary and Alternative Medicine. Volume 2017; Article ID 5294890, 15 pages [cited 2017 Sept 21]. Available from:

https://www.hindawi.com/journals/ecam/2017/5294890/

Vandamme L, Heyneman A, Hoeksema H, Verbelen J, Monstrey S. Honey in modern wound care: a systematic review. Burns. 2013;39(8):1514-1525.

Vandeputte J, Van Waeyenberge PH. Clinical evaluation of L-Mesitran ${ }^{\circledR}$ - a honey-based wound ointment. Professional Nursing Today. 2007;11(2):26-31.

Watts R, Frehner E. Evidence summary: wound management: medical-grade honey. Wound Practice and Research. 2016;24(1):61-64. 